\title{
Services to Developmental Education Students in the Community College: Does the Library Have a Role?
}

\section{Carol Truett}

A recent survey of Texas community college libraries revealed that although over 90 percent of these colleges had a well-developed developmental education program, less than 28 percent of the schools provided a large number of library services to such programs. The results of this research agreed with two previous studies made in other parts of the country, which surveyed library services to developmental programs and found such services to be nonexistent or minimal. Special library instruction for developmental students and bilingual handbooks were two notable areas lacking in the majority of colleges. While certain institutional variables characterized those schools offering a high level of library services to developmental programs, no correlation was found between student persistence rates measured in terms of the percent of students remaining in classes at the end of a semester as a total percentage of those enrolled at the beginning of the semester, and the level of library service offered to developmental studies students.

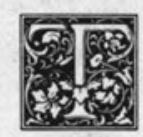

he role which the communitycollege library/learning resource center should play in the education of developmental education students seems so selfevident to most librarians that it is surprising to discover the paucity of research on this subject. Lombardi defines developmental education as that segment of the community-college curriculum that is comprised of pre-transfer, handicapped, remedial, and adult basic education (ABE) courses. ${ }^{1}$ Although developmental education, according to Lombardi, is often used synonymously with the term remedial, the trend today is to define it in broader terms than just those courses and programs for the academically disadvantaged. This new definition includes any courses that help students "overcome any deficiencies they have in their preparation for postsecondary education. ${ }^{\prime \prime 2}$ Lombardi predicts that developmental education in its broadest definition will grow to comprise 50 percent of college enrollments within the next decade. The research described in this paper limited the definition of developmental education by excluding the handicapped.

\section{SURVEYS OF LIBRARY SERVICES TO \\ DEVELOPMENTAL STUDENTS}

Only two surveys could be found that attempted to describe the provision of library services to developmental studies college students on a comparative basis. Shaughnessy ${ }^{3}$ surveyed eight publicly supported urban colleges and universities on a national level while Breivik' ${ }^{4}$ study

Carol Truett is assistant professor, Department of Educational Administration, University of Nebraska, Lincoln. 
was limited to responses from ten of the thirteen City University of New York colleges in existence before 1970 , serving freshmen level students. Both drew similar conclusions-that, in general, the libraries had not recognized the special needs of their educationally disadvantaged students. However, both also found that in those few exceptional cases where special staff was assigned to work with developmental students and faculty, there was a distinct, and generally successful, program of services offered to those students.

There is a good deal of evidence that the community-college learning resource center or library has a great deal to offer to developmental education students. Breivik, for example, reported on the results of research at Brooklyn College, where developmental English students received course-related, integrated library instruction from the college librarians for one semester. Their performance on four criteria were compared with similar groups of English classes who received no library instruction or the traditional library orientation lecture/tour. Those with the library instruction made the greatest academic gain measured in terms of ability to produce a research paper and in the area of student retention. Fewer members of this group dropped out of their English courses during the semester and even completed the following semester with credit, as compared with students having no library instruction. Breivik also discovered that those with no library instruction surpassed those who had had the typical orientation treatment in the areas indicated. Wagner ${ }^{6}$ claimed that extensive library-based instruction included as part of a basic English course at Upsala College in East Orange, New Jersey, not only caused total class performance to go up, but resulted in even greater overall improvement and quality of work for the developmental high-risk students in the class than the class average.

Various other authors have described special library programs that have addressed the needs of special groups who were either developmental students at the time, or would most likely be channeled into such courses when they actually enrolled. Many of these students are ethnic minority-group members, but developmental students actually are comprised of more non-minority-group members than minorities according to Cross, ${ }^{7}$ who says that two-thirds of these students are simply the children of blue-collar workers who ceased their own formal education at an early age.

Mallory ${ }^{8}$ has described library services and instruction to the SEEK (Search, Education and Elevation for Knowledge) students at Queens College in the late 1960s. Two other authors, Wright, ${ }^{9}$ who also worked with SEEK students, and Josey, ${ }^{10}$ who describes the efforts of the City University of New York to make the openadmissions policy a success through involvement of the library as an integral support service, point out some of the potential activities that librarians can offer to aid developmental students. According to Josey, such services include: (1) special library counseling, (2) reading guidance, (3) instruction, (4) special tutorial services in the library, and (5) selective dissemination of information utilizing honors students and other service-oriented volunteer groups to match the resources of the library with the needs of disadvantaged students. Trejo ${ }^{11}$ relates the special problems of Spanish-speaking students who are often disadvantaged both culturally and in their use of the English language and who thus frequently end up in developmental education classes. And Dudley ${ }^{12}$ has documented a special library program aimed at Spanish-speaking Chicano students at the University of California at Los Angeles. These students lacked normal entrance requirements but showed promise of academic success and were thus admitted under the university's High Potential Program, called the Chicano Library Program. This special instruction basically consisted of a one-quarter, no-credit course. It required students to spend two hours every afternoon, five days a week, in the library working on a series of sixteen self-paced tasks designed to teach them how to use the library. This program was so successful it was expanded to include not only blacks, but Indian and Oriental 
high-potential students as well.

Though modest compared to UCLA's program, a special Spanish slide/tape library orientation program geared to its bilingual students was produced by Passaic County Community College in Paterson, New Jersey. ${ }^{13}$ Haro $^{14}$ further delineates the cultural difficulties and frustrations confronting the Mexican American student that often create academic difficulties.

Finally, numerous authors and researchers besides Breivik have attempted to address the relationship between college support services, including libraries and student retention. One survey of twoyear college administrators found that a large percentage of those polled felt "inadequate institutional support to students" was "one of the three major reasons of attrition. ${ }^{\prime 15}$ Medsker and Tillery consider the low persistence rate of the community college student to be an area of serious criticism: "The public community college has been criticized for its lack of holding power." ${ }^{16}$ They cite attrition rates of 50 percent and more for the twoyear student body:

It is appropriate that concern about the lack of persistence among community college students be expressed. The record would suggest that the colleges themselves are failing to offer programs and services of a nature and in a manner that hold students. This problem should be one of the greatest priorities for research . . . ${ }^{17}$

In fact, one study attempts to tie attrition rates directly to library use. This research was conducted at California State Polytechnic University, at Pomona, by Lloyd and Martha Kramer, who concluded that freshman use of the library, as evidenced by library-book borrowing, is correlated to student retention:

... of those freshmen who failed to use the library, 43 percent did not return the following year. But of those who did borrow at least one book, only 26 percent dropped out. ${ }^{18}$

Thomas Atkins, president of the Library Association of New York during the early stages of the City University's openadmissions policy, claimed that any initial difficulties faced by potential developmental students will increase their negative self-image, and he considers the pos- session of inadequate library skills a potential first step in the dropout process, for these skills are necessary to prepare almost any type of college writing assignment. ${ }^{19}$ Thus, the research described in this study was an attempt to see if community-college libraries in a particular state with a well-developed two-year college system were providing services to developmental education students or programs. If so, did these services appear to make any difference in terms of student persistence?

\section{METHODOLOGY: SURVEY OF TEXAS COMMUNITY COLLEGE LIBRARY SERVICES TO \\ DEVELOPMENTAL STUDIES STUDENTS}

During the $1979-80$ academic year, a ten-page questionnaire was sent to the head librarian or director of fifty-two publicly supported, two-year community colleges in the state of Texas to determine the answer to several questions: (1) What role was the community-college library/LRC playing in the education of developmental studies students in this particular state? (2) What institutional factors, if any, appeared related to a high level of library services to developmental programs? (3) Was special library instruction being made available to developmental students in an effort to bolster their information-seekingand-handling skills? (4) Was student achievement as measured by student persistence rates in three areas-collegewide, in developmental studies courses overall, and in developmental Englishrelated to the degree or number of library services provided to developmental students? Student persistence was defined as the number of students still enrolled at the end of a semester as a percent of those who had been enrolled at the beginning of the respective course or courses.

Of the forty-six returned questionnaires, forty-three were usable, giving a return rate of almost 83 percent. Both descriptive analysis and correlational analysis were performed on the resulting data secured from the questionnaire which had 
been field-tested by both practitioners in the field as well as professors in the area of library science and educational administration. As part of the general descriptive analysis, the following statistics were run: frequencies, means, and standard deviations. As part of the correlational analysis, five additional statistical analyses were performed. These included breakdowns, cross tabulations, Pearson's correlation, T-tests of significance, and discriminant analysis. Discriminant analysis, in particular, was useful in determining whether or not there were two or more clearly defined groups of community colleges offering different levels of library services to developmental education students. The groups resulting from this discriminant analysis were then used to determine if a correlation existed between level of library service to developmental students and student persistence rates.

\section{FINDINGS}

The community colleges responding to the survey displayed tremendous diversity in their basic institutional characteristics. For example, they ranged in size from 536 to 27,114 students. Total institutional budgets varied from under $\$ 38,000$ for academic $1978 / 79$ to well over a million dollars. Nineteen of the colleges were multicampus institutions and twenty-four consisted of a single main campus. However, in the area of developmental studies, the colleges were remarkably similar with 90 percent, or thirty-nine colleges, offering developmental courses to their students. Developmental courses, as previously defined, included any courses that helped students overcome any deficiencies they had in their preparation for college-level course work. Most of the colleges, in fact, had a well-developed program with a mean number of courses offered of 5.1 out of a possible total of 7 (see tables 1 and 2).

The most frequently offered course was developmental reading, taught at 97.4 percent of responding institutions (all but one school providing a developmental program offered it). Next in order of most frequently taught courses were: developmental English (87.2 percent), developmental mathematics ( 84.6 percent), developmental writing (76.9 percent), adult basic education ( 66.7 percent), and other courses (33.3 percent). Most colleges (over

TABLE 1

TEXAS COMMUNITY COLLEGES WITH DEVELOPMENTAL STUDIES PROGRAMS

\begin{tabular}{lrcc}
\hline \hline Category & Number & $\begin{array}{c}\text { Percent } \\
\text { of Total }\end{array}$ & $\begin{array}{c}\text { Percent } \\
\text { Adjusted }\end{array}$ \\
\hline Colleges with developmental studies programs & 39 & 90.7 & 92.9 \\
No program & 3 & 7.0 & 7.1 \\
No response & 1 & 2.3 & - \\
$\quad$ Total number reporting & 42 & & \\
\hline
\end{tabular}

TABLE 2

TEXAS COMMUNITY-COLLEGE DEVELOPMENTAL STUDIES PROGRAM COURSE OFFERINGS

\begin{tabular}{lcc}
\hline \hline Course & Number & Percent of Respondents \\
\hline Developmental English & 34 & 87.2 \\
Developmental writing & 30 & 76.9 \\
Developmental reading & 38 & 97.4 \\
Developmental mathematics & 33 & 84.6 \\
ABE (adult basic education) & 26 & 66.7 \\
Study skills course & 24 & 61.5 \\
Other courses & 13 & 33.3 \\
$\quad$ Total number reporting & 39 & \\
No response & 4 & \\
\hline
\end{tabular}

NOTE: Nonrespondents included one who did not answer and three who checked a "no" response to the question asking whether or not the college had a developmental studies program. 
TABLE 3

SPECIAL LIBRARY SERVICES TO DEVELOPMENTAL EDUCATION STUDENTS IN TEXAS COMMUNITY COLLEGES

\begin{tabular}{lrr}
\hline \hline & $\begin{array}{c}\text { Number of } \\
\text { Colleges } \\
\text { Providing }\end{array}$ & $\begin{array}{c}\text { Percent of } \\
\text { Respondents }\end{array}$ \\
\hline Lervice & 34 & 82.9 \\
Library instruction & 18 & 43.9 \\
Library handbook & 1 & 2.4 \\
Special edition of handbook & 1 & 2.4 \\
Bilingual handbook & 22 & 53.7 \\
Audiovisual orientation & 10 & 24.4 \\
Bibliographies & 11 & 26.8 \\
Tutoring & 3 & 7.3 \\
Tutoring by library personnel & 11 & 26.8 \\
Tutoring in library by nonlibrary personnel & 12 & 29.3 \\
Learning center in library & 5 & 12.2 \\
Learning center administered by library & 13 & 31.7 \\
Personalized reference work (counseling) & 41 & 2 \\
$\quad$ Total number reporting & 2 & \\
$\quad$ No response & & \\
\hline
\end{tabular}

70 percent) gave college credit for their developmental studies courses.

Twelve possible library services that could be offered to developmental education students were used to create an Index of LRC Services to Developmental Education Programs (see tables 3 and 4). Library instruction was clearly the most prevalent service offered, with 82.9 percent providing it. Analysis of library instruction methods used resulted in table 5, which lists in rank order the ten most popular methods. It is obvious that library instruction is considered synonymous with the traditional orientation lecture/tour by many librarians and the high incidence of this method in Texas is comparable to figures collected on a national basis. ${ }^{20}$ It is very significant, however, that more than two-thirds $(69.8$ percent) also reported offering courserelated instruction in their college and most colleges used a wide variety of methods, which averaged over six methods per school. This perhaps indicates a willingness to accommodate the wide range of abilities and learning styles found among community college students. Thus, it appeared that both the worst method (the orientation lecture/tour) and the best method (course-related instruction), according to previous research on the developmental student, were being offered side by side.

Unfortunately, special library instruction to developmental students was not being provided at almost 63 percent of the colleges, as table 6 shows. It is not clear whether librarians felt these students received adequate instruction in other

TABLE 4

LRC SERVICES TO DEVELOPMENTAL EDUCATION PROGRAMS INDEX

\begin{tabular}{lcc}
\hline \hline Index & Number & Percent \\
\hline Lo, few services & & \\
$0-2$ & 19 & 44.2 \\
Average services & 12 & 27.9 \\
3-4 & & \\
Hi services & 12 & 27.9 \\
5-10 & 10.0 & \\
$\quad$ Range & 3.3 & \\
Mean & 2.8 & \\
Median & 43 & \\
$\quad$ Total number cases & & \\
\hline
\end{tabular}

TABLE 5

TEN MOST POPULAR LIBRARY SKILLS METHODS RANK ORDERED BY PERCENT OF COLLEGES UTILIZING

\begin{tabular}{lc}
\hline \hline Method & Percent \\
\hline 1. Library tour & 93.0 \\
2. Orientation lecture & 83.7 \\
3. Course-related instruction & 69.8 \\
4. Handbooks & 62.8 \\
5. Point of use aids & 51.2 \\
6. Slide/tapes & 44.2 \\
7. Credit course & $34.9^{\star}$ \\
7. Textbooks, manual, guides & $34.9^{\star}$ \\
8. Term-paper clinics & 32.6 \\
9. Self-paced instruction & 27.9 \\
10. Audio tapes & 25.6 \\
\hline
\end{tabular}

"These two methods were tied for seventh place. 
TABLE 6

PROVISION OF SPECIAL LIBRARY INSTRUCTION TO DEVELOPMENTAL STUDIES STUDENTS

\begin{tabular}{lcc}
\hline \hline Category & Number & $\begin{array}{r}\text { Percent } \\
\text { of Total }\end{array}$ \\
\hline $\begin{array}{l}\text { Library provides special } \\
\text { instruction to }\end{array}$ & & \\
$\begin{array}{l}\text { developmental students } \\
\text { No special instruction is }\end{array}$ & 16 & 37.2 \\
$\begin{array}{l}\text { provided } \\
\text { Total number reporting }\end{array}$ & 27 & 62.8 \\
$\quad$ No response & 43 & \\
\hline
\end{tabular}

courses or whether they simply did not consider such instruction necessary; however, almost a third of the colleges did provide special user instruction for such courses and programs as English literature, criminal justice, business, health careers and nursing, communications, and even horology. Lolley and Watkins ${ }^{21}$ claimed that developmental students who need library skills the most appeared the least likely group to receive such instruction, and the results of this study confirm their contention.

Despite being the most frequently offered service to developmental students, library instruction was notable for its absence at many institutions. Although 31 percent of the community-college libraries reported that $90-100$ percent of their students received instruction, half of the colleges indicated that only 59 percent or less of their students were taught library skills, with one school reaching less than 1 percent! On the other hand, librarians did assume a responsibility for teaching library skills at the majority of colleges. All but one ( 97.6 percent) of the librarians agreed with the statement that librarians should teach library skills to students. Library staff shared this responsibility with faculty at seventeen institutions (39.5 percent) and assumed sole responsibility at twenty-two schools ( 51.2 percent).

Despite the large Mexican American population in many major Texas cities (e.g., 86 percent and 52 percent are Hispanic in Brownsville and San Antonio, respectively), only one school had a bilingual handbook. All major cities or towns in Texas that have large Spanish-speaking segments are bilingual cities. Signs in public facilities, instructions for such activities as voting and buying licenses, and all written communications sent home with public school children are in both English and Spanish. Therefore, it seems logical to assume that library handbooks might also be available in public community-college libraries in a Spanish edition.

\section{Other Library Services}

Again referring to table 3, it may be seen that other library services offered to developmental education students by between one-fourth to one-third of the colleges included bibliographies ( 24.4 percent), tutoring ( 26.8 percent), tutoring in library by nonlibrary personnel (26.8 percent), learning center in the library (29.3 percent), and personalized reference work or counseling (31.7 percent). The largest number of services provided by any one college was 10 , although the mean number of library services offered was only 3.3. As table 4 indicates, 44.2 percent of the colleges, or nineteen schools, fell in the low-level-of-services category and even as generously defined as the high-services category was (i.e., five to ten services out of a possible twelve), only slightly more than one-fourth of the colleges, or twelve institutions, could be thus classified. In other words, most of the colleges were providing a very small number of special services to developmental education students. Furthermore, the librarians surveyed felt that services to the disadvantaged student were adequate; more than 76 percent agreed with this statement in regard to their school. On the other hand, more than half of the librarians queried ( 56 percent) felt their college should offer more services to disadvantaged students. Thus, there appeared to be both complacency and yet ambivalence toward present library services to developmental students, despite the fact that most of the community colleges were offering few such services. In fact, foreign and ESL (English as a Second Language) students were singled out twice as frequently as developmental students (almost 42 percent combined versus 19 percent for remedial students) for special library services. And 
a number of write-in comments indicated that many librarians apparently resented the idea of singling out any particular group for special service.

\section{No Correlation between Library Services and Student Persistence}

In view of the minimal special library services being provided to developmental students at most of the community colleges in the survey, it was not too surprising to find no correlation between the number of library services being provided to developmental education programs and student persistence college-wide, in developmental programs overall, or in remedial English courses. This is particularly true when one considers the enormous number of other variables that can affect a student's decision to persist or withdraw during the course of a semester-personal, economic, psychological, and institutional factors - to name but a few.

Certain institutional variables, on the other hand, were found to be related to a high number of library services to developmental programs: size of college in terms of size of faculty and student enrollment; size of the budget, both in absolute terms and as a percentage of total institutional budget; the amount specifically expended by the library/LRC for developmental studies; and the number of library staff members, in terms of total number of positions and total number of professional librarians. Number of book volumes or audiovisual materials, however, did not appear to be an important concomitant of a large number of library services to developmental education, although expendi- tures for the latter were relevant. This may indicate a point of diminishing returns so far as collection size is concerned for both print and nonprint materials, although more service-minded library/LRCs probably attempt to keep their audiovisual collections current and viable by allocating sufficient funds on a continuing basis.

Other findings of the study revealed that Texas community colleges do not routinely assign professional librarians to work with developmental studies departments, and where such assignments are made, very little time is spent on such duties which average about two and a half hours per week. Moreover, only 14 percent of the colleges spent more than 3 percent of the library budget on developmental studies, including both materials and services; an important indicator of what an institution values or considers important is generally felt to be reflected by what it spends money on. Lack of time and funds were offered as excuses for not offering more library services to developmental students.

Another important finding confirmed the low minority-group representation among library staff members and the fact that minority representation among development students was far greater than that of library employees. (See tables 7 and 8.) To test whether there was a statistically significant difference in ethnic representation between the LRC staff and the developmental studies students, a simple correlated $T$-test was run, using paired samples to test the differences in means. As table 9 shows, only one correlation, that for Anglo representation, was found to have a nonsignificant, no difference in

TABLE 7

ETHNIC REPRESENTATION OF

DEVELOPMENTAL STUDIES STUDENTS

\begin{tabular}{ccccc}
\hline \hline $\begin{array}{c}\text { Variable } \\
\text { Number }\end{array}$ & $\begin{array}{c}\text { Ethnic } \\
\text { Group }\end{array}$ & $\begin{array}{c}\text { Number of Colleges } \\
\text { with Group } \\
\text { Represented }\end{array}$ & $\begin{array}{c}\text { Percent } \\
\text { of Total }\end{array}$ & $\begin{array}{c}\text { Percent } \\
\text { Adjusted }\end{array}$ \\
\hline 1 & Anglo & 36 & 83.7 & 97.3 \\
2 & Mexican American & 34 & 79.1 & 91.9 \\
3 & Black & 35 & 81.4 & 94.6 \\
4 & Oriental & 25 & 58.1 & 67.6 \\
5 & Other & 17 & 39.5 & 45.9 \\
\multicolumn{2}{l}{ Total number reporting } & 37 & & \\
\hline
\end{tabular}


TABLE 8

ETHNIC REPRESENTATION OF LIBRARY LEARNING RESOURCES CENTER STAFF

\begin{tabular}{clccr}
\hline \hline $\begin{array}{c}\text { Variable } \\
\text { Number }\end{array}$ & \multicolumn{1}{c}{$\begin{array}{c}\text { Ethnic } \\
\text { Group }\end{array}$} & $\begin{array}{c}\text { Number of Colleges } \\
\text { with Group } \\
\text { Represented }\end{array}$ & $\begin{array}{c}\text { Percent } \\
\text { of Total }\end{array}$ & $\begin{array}{r}\text { Percent } \\
\text { Adjusted }\end{array}$ \\
\hline 6 & Anglo & 39 & 90.7 & 100.0 \\
7 & Mexican American & 23 & 53.5 & 59.0 \\
8 & Black & 25 & 58.1 & 64.1 \\
9 & Oriental & 5 & 11.6 & 12.8 \\
10 & Other & 3 & 7.0 & 7.7 \\
Total number reporting & 39 & & \\
No response & & 4 & & \\
\hline
\end{tabular}

TABLE 9

CORRELATED T-TEST OF SIGNIFICANCE USING PAIRED SAMPLE MEANS OF DEVELOPMENTAL STUDIES AND LRC STAFF ETHNIC GROUP REPRESENTATION

\begin{tabular}{|c|c|c|c|c|c|c|c|c|c|c|}
\hline $\begin{array}{l}\text { Variable' } \\
\text { Number }\end{array}$ & $\begin{array}{l}\text { No. of } \\
\text { Cases }\end{array}$ & Mean & $\begin{array}{l}\text { Standard } \\
\text { Deviation }\end{array}$ & $\begin{array}{l}\text { Standard } \\
\text { Error }\end{array}$ & $\begin{array}{l}\text { (Difference) } \\
\text { Mean }\end{array}$ & $\begin{array}{l}\text { Standard } \\
\text { Deviation }\end{array}$ & $\begin{array}{c}\text { Standard } \\
\text { Error }\end{array}$ & $\begin{array}{c}T \\
\text { Value }\end{array}$ & $\begin{array}{c}\text { Degrees } \\
\text { of } \\
\text { Freedom }\end{array}$ & $\begin{array}{l}\text { 2-Tail } \\
\text { Prob. }\end{array}$ \\
\hline $\begin{array}{c}1 \\
\text { with } \\
6\end{array}$ & 36 & $\begin{array}{r}.9722 \\
1.0000\end{array}$ & $\begin{array}{r}.167 \\
0\end{array}$ & $\begin{array}{r}.028 \\
\times \quad 0\end{array}$ & -.0278 & .167 & .028 & -1.00 & 35 & .324 \\
\hline $\begin{array}{c}2 \\
\text { with } \\
7\end{array}$ & 36 & $\begin{array}{l}.9167 \\
.6389\end{array}$ & $\begin{array}{l}.280 \\
.487\end{array}$ & $\begin{array}{l}.047 \\
.081\end{array}$ & .2778 & .513 & .086 & 3.25 & 35 & .003 \\
\hline $\begin{array}{c}3 \\
\text { with } \\
8\end{array}$ & 36 & $\begin{array}{l}.9444 \\
.6389\end{array}$ & $\begin{array}{l}.232 \\
.487\end{array}$ & $\begin{array}{l}.039 \\
.081\end{array}$ & .3056 & .467 & .078 & 3.92 & 35 & .000 \\
\hline $\begin{array}{c}4 \\
\text { with } \\
9\end{array}$ & 36 & $\begin{array}{r}.6944 \\
.1389\end{array}$ & $\begin{array}{l}.467 \\
.351\end{array}$ & $\begin{array}{r}.078 \\
.058\end{array}$ & .5556 & .504 & .084 & 6.61 & 35 & .000 \\
\hline $\begin{array}{c}5 \\
\text { with } \\
10\end{array}$ & 36 & $\begin{array}{l}.4722 \\
.0833\end{array}$ & $\begin{array}{r}.506 \\
.280\end{array}$ & $\begin{array}{l}.084 \\
.047\end{array}$ & .3889 & .599 & .100 & 3.90 & 35 & .000 \\
\hline
\end{tabular}

means between the two groups. All of the other correlations resulted in a difference with a highly significant $T$-value (significant beyond the .01 level), indicating that a wide discrepancy exists between minority group representation on library staffs and that found among developmental students.

\section{RECOMMENDATIONS AND CONCLUSION}

The results of this study basically confirm the earlier surveys of both Shaughnessy and Breivik, which revealed the existence of a low level of library services to developmental college students. Leading community-college developmental education spokespersons such as John
Lombardi and John E. Roueche $\mathrm{e}^{22}$ do not see the developmental studies or remedial mission of the community college as diminishing in importance. The results of this study serve to highlight the disparity between developmental program course offerings of community colleges and the provision of library services to such programs. The majority of Texas community college libraries, in fact, provide a low level of services to these programs and, furthermore, the prognosis for change is not particularly bright since most librarians seem satisfied with current services. Texas has the potential to become a leader in the field of library services to community-college developmental education students, yet it does not appear to 
have reached this status.

Perhaps the time has come for community-college librarians to look more closely at institutional priorities. If the role of the modern community-college library is to support the curriculum offerings, and if developmental education grows to constitute 50 percent of the communitycollege curriculum as Lombardi has pre- dicted, then present library services are going to become less and less relevant to the needs of community college students unless some sort of reassessment is forthcoming. Although Texas was the focus of this particular study, there is no reason to suppose that the situation is more favorable in any other part of the country.

\section{REFERENCES}

1. John Lombardi, "Developmental Education: A Rapidly Expanding Function," Community College Review 7:65-72 (Summer 1979).

2. Cuyahoga Community College (Ohio), Conference Proceedings: Annual Ohio Developmental Education Conference, $2 d$ Cleveland, October 6-7, 1974 (Cleveland: ERIC Document Reproduction Service, 1975), ED 104460.

3. Thomas W. Shaughnessy, "Library Services to Educationally Disadvantaged Students," College E Research Libraries 36:443-48 (Nov. 1975).

4. Patricia Senn Breivik, Open Admissions and the Academic Library (Chicago: American Library Assn., 1977).

5. Patricia Senn Breivik, "Resources: The Fourth R," Community College Frontiers 5:46-50 (Winter 1977).

6. Walter Wagner, "On Integrating Libraries and Classrooms," Learning Today 6:48-62 (Winter 1973).

7. K. Patricia Cross, Beyond the Open Door (San Francisco: Jossey-Bass, 1972).

8. Mordine Mallory, "The New College Student and the Library: The SEEK Program at Queens College," in A New College Student: The Challenge to City University Libraries (Rockaway Park, N.Y.: Scientific Book Service, 1969), p.32-40.

9. Sylvia Hart Wright, "A Pre-College for the Disadvantaged," Library Journal 95:2884-87 (Sept. 15, 1970).

10. E. G. Josey, "The Role of the Academic Library in Serving the Disadvantaged Student," Library Trends 20:432-44 (Oct. 1971).

11. Arnulfo D. Trejo, "Library Needs for the Spanish-Speaking," ALA Bulletin 63:1079-81 (Sept. 1969).

12. Miriam Sue Dudley, Chicano Library Program, UCLA Library Occasional Papers, no.17 (Los Angeles: Univ. of California Library, 1970).

13. J. Martinelli, "Bilingual Slide-Tape Library Orientation: An Unexplored Frontier," Audiovisual Instruction 21:55-56 (Jan. 1976).

14. Robert P. Haro, "Academic Library Services for Mexican-Americans," College \& Research Libraries 33:454-62 (Nov. 1972).

15. James L. Morrison and Reynolds Ferrante, Why the Disadvantaged Drop Out: The Administrators View (Bethesda, Md.: ERIC Document Reproduction Service, 1973), ED 071665.

16. Leland L. Medsker and Dale Tillery, Breaking the Access Barriers: A Profile of Two-Year Colleges (New York: McGraw-Hill, 1971).

17. Ibid.

18. Lloyd A. Kramer and Martha B. Kramer, "The College Library and the Drop-Out," College \& Research Libraries 29:310-12 (July 1968).

19. Thomas V. Atkins, "Libraries and Open Admissions," LACUNY Journal 1:3-7 (Winter 1972).

20. John Lolley, "Instruction in Junior and Community Colleges," in John Lubans, Jr., ed., Progress in Educating the Library User (New York: Bowker, 1978), p.57-69.

21. John Lolley and Ruth Watkins, "Welcome to the Library," Journal of Developmental and Remedial Education 3:25-26 (Fall 1979).

22. John E. Roueche and Oscar Mink, Holistic Literacy in College Teaching (New York: Media Systems, 1980). 